\title{
Health Risk of Maâmora's Groundwater Pollution in Morocco
}

\author{
Imane Kherrati1, A. Alemad1, M. Sibbari1,2, H. Ettayea1,3, K. Ezziani1,4, Y. Saidi1, \\ M. Benchikh'1, S. Alzwi'1, H. Chiguer ${ }^{1}$, Z. Zgourdah'1, A. Bourass'1, H. Daifi' ${ }^{1}$, \\ 0. Elrhouat ${ }^{1}$, K. Elkharrim ${ }^{1}$, D. Belghyti ${ }^{*}$ \\ ${ }^{1}$ Laboratory Environment \& Renewable Energy, Faculty of Sciences, University Ibn Tofail, Kenitra, Morocco \\ ${ }^{2}$ National Office of Water and Electricity (ONEE), Skhirat, Morocco \\ ${ }^{3}$ Self-Governed Water and Electricity Kenitra (RAK), Morocco \\ ${ }^{4}$ National Office of Drinking Water (ONEP), Rabat, Morocco \\ Email: imane fac@hotmail.com,
}

Received 11 October 2014; accepted 20 April 2015; published 22 April 2015

Copyright (C) 2015 by authors and Scientific Research Publishing Inc.

This work is licensed under the Creative Commons Attribution International License (CC BY).

http://creativecommons.org/licenses/by/4.0/

c) (i) Open Access

\begin{abstract}
The problem of pollution affects the whole world groundwater. The purpose of our present study is to evaluate the impact of contamination from residues of industry and agriculture, and discharge of untreated domestic wastewaters on the physical, chemical, metal and bacteriological water quality of Maâmora's tablecloth (Sebou bassin, Kenitra, Morocco). The physicochemical parameters followed are: $\mathrm{T}{ }^{\circ} \mathrm{C}, \mathrm{pH}, \mathrm{EC}, \mathrm{NH}_{4}^{+}, \mathrm{NO}_{2}^{-}, \mathrm{NO}_{3}^{-}, \mathrm{Cl}^{-}, \mathrm{F}^{-}, \mathrm{HCO}_{3}^{-}, \mathrm{CO}_{3}^{2-}, \mathrm{SiO}_{2}, \mathrm{SO}_{4}^{2-}, \mathrm{Na}^{+}, \mathrm{Ca}^{2+}$, $\mathrm{Mg}^{2+}, \mathrm{K}^{+}, \mathrm{Pb}^{2-}, \mathrm{Cd}^{2+}, \mathrm{Fe}^{2+}, \mathrm{Cu}^{2+}, \mathrm{Zn}^{2+}, \mathrm{Ni}^{2+}, \mathrm{B}^{3+}$, Dry Residue, Turbidity, Total Hardness (TH), Dissolved $\mathrm{O}_{2}$, Oxidisability, total and fecal coliforms, faecal streptococci and total and faecal germs of raw water from the boreholes. The physical, chemical, metal and bacteriological quality shows that the groundwater which is used as drinking water in the city of Kenitra and adjacent towns is generally good. However, high concentrations of nitrates (over $210.8 \mathrm{mg} / \mathrm{L}$ ) and other metals (185 $\mu \mathrm{g} / \mathrm{l}$ for lead; 58.98 for nickel; $187.3 \mu \mathrm{g} / \mathrm{L}$ for iron; $2204 \mu \mathrm{g} / \mathrm{L}$ for zinc) in some wells are worrisome because of the serious health consequences.
\end{abstract}

\section{Keywords}

Groundwater, Physicochemical, Microbiological, Metals, Kenitra, Morocco

\section{Introduction}

In Morocco, groundwater is an important part of the hydraulic heritage of the country [1]. Groundwater, is in "Corresponding author.

How to cite this paper: Kherrati, I., Alemad, A., Sibbari, M., Ettayea, H., Ezziani, K., Saidi, Y., Benchikh, M., Alzwi, S., Chiguer, H., Zgourdah, Z., Bourass, A., Daifi, H. Elrhouat, O., Elkharrim, K. and Belghyti, D. (2015) Health Risk of Maâmora's Groundwater Pollution in Morocco. Natural Resources, 6, 290-305. http://dx.doi.org/10.4236/nr.2015.64026 
principle protected geologically, but unfortunately it can be polluted by agriculture, industry, and urban planning.

In this coastal region, in addition to marine disturbances (seawater intrusion), water resources are increasingly threatened by pollution from urban, agricultural, industrial and artisanal origin. Indeed, this urbanization has led to demands for ever increasing water. Pollution of groundwater is one of the most disturbing aspects and the use of these waters for food is a health hazard. Given the high demand for water for demographic growth and related industrial development, water pollution is increasing day by day [2]. The Reference [3] estimates that $80 \%$ of diseases that affect the world's population are directly related to water, which implies the need to treat it.

This work focuses on the study of the quality of the Maâmora's groundwater. The analyses of groundwater in the study area were made in Laboratory of the National Office of Drinking Water (ONEP), Regional Office of Agricultural Development in Gharb (ORMVAG), Autonomous Water and Electricity Authority of Kenitra (RAK) and in the Laboratory of Environment and Renewable Energies of Faculty of Sciences, Kenitra, Morocco.

\section{Material and Methods Study}

\subsection{Area Study}

Maâmora, which is a $2300 \mathrm{~km}^{2}$ basin, is bordered on the north by the tablecloth Tiflete, to the east by the river Beht, and west by the Atlantic sea. North of the study area, the Gharb basin shows a very gentle terrain in its central part. In contrast, in the western and eastern part, its altitude is $20 \mathrm{~m}$. The Maâmora basin has a slope of $6 \%$ to the NNW, culminates in the SE at around 250 meters and has more on the outskirts of Gharb, an altitude of 10 to 30 meters. The overall morphology is a succession of hills and valleys parallel to the shore in a mean direction $\mathrm{N} 030^{\circ} \mathrm{E}$ and $\mathrm{N} 130^{\circ} \mathrm{E}$ locally at 150 . Mâamora is characterized by a well developed river system from west to east. The main rivers are Sebou, Fouarate, Semento, Tiflete, Touirza, Tahrest, and Mellah. The Oued Fouarate with a total length of about $40 \mathrm{~km}$, occupies the western valley. The area of its basin is about $285 \mathrm{~km}^{2}$. In its upper reaches, Fouarate river management has a $\mathrm{N} 150^{\circ} \mathrm{E}$, and then curves to the NW with a mean direction $\mathrm{N} 030^{\circ} \mathrm{E}$ in the downstream portion of his career, to finally throw in the Sebou river [4]. The city of Kenitra is located $40 \mathrm{~km}$ north of Rabat, the capital of the Kingdom of Morocco. It is bounded by the Sebou river in the north, Lake Fouarat in the east and Forest Maâmora in southwest (Figures 1-3). The objective of this work is to take a sample of 10 drillings in March-April 2010 (ONEP), 6 of 21 drillings in March-June 2012 (RAK), 5 wells 2013 (ORMVAG) and 6 wells (EER) from January to October 2014 (Table 1).

\subsection{Study Methods}

For samples of raw water of Maâmora, we conducted bacteriological (fecal coliforms, total coliforms), physical, chemical and metal analyses $\left(\mathrm{T}{ }^{\circ} \mathrm{C}, \mathrm{pH}, \mathrm{EC}, \mathrm{NH}_{4}^{+}, \mathrm{NO}_{2}^{-}, \mathrm{NO}_{3}^{-}, \mathrm{Cl}^{-}, \mathrm{F}^{-}, \mathrm{HCO}_{3}^{-}, \mathrm{CO}_{3}^{2-}, \mathrm{SiO}_{2}, \mathrm{SO}_{4}^{2-}, \mathrm{K}^{+}, \mathrm{Na}^{+}\right.$, $\mathrm{Ca}^{2+}, \mathrm{Mg}^{2+}, \mathrm{Pb}^{2-}, \mathrm{Cd}^{2+}, \mathrm{Cu}^{2+}, \mathrm{Zn}^{2+}, \mathrm{Ni}^{2+}, \mathrm{Fe}^{2+}, \mathrm{B}^{3+}$, Dry Residue, Turbidity, Alcalinity (TAC), Total Hardness (TH), Dissolved $\mathrm{O}_{2}$, Oxidisability).

The samples at the pumps are made after buckling tap and extended in order to have a permanent water quality pumping. The water samples are collected in $500 \mathrm{ml}$ bottles kept refrigerated cooler $\left(4^{\circ} \mathrm{C}\right)$ until analysis (Figure 4). The following physicochemical parameters are performed using the techniques of Rodier [5]. Temperature, potential $(\mathrm{pH})$ and electrical conductivity (EC) were measured "in situ" using a portable multiparameter (Consort model 835C). Nitrate $\left(\mathrm{NO}_{3}^{-}\right)$, nitrite $\left(\mathrm{NO}_{2}^{-}\right)$, ammonia nitrogen $\left(\mathrm{NH}_{4}^{+}\right)$, silicate $\left(\mathrm{SiO}_{2}\right)$, boron $\left(\mathrm{B}^{3+}\right)$, fluoride $\left(\mathrm{F}^{-}\right)$and sulfate $\left(\mathrm{SO}_{4}^{2-}\right)$ are determined by colorimetric assay using a spectrophotometer $(\mathrm{UV} /$ visible Lampa 2). Hardness (TH) is measured by the volumetric method using EDTA. The oxidisability (oxidizable materials: $\mathrm{MO}$ ) is determined by temperature oxidation in acidic medium.

Bicarbonates $\left(\mathrm{HCO}_{3}^{-}\right)$are analyzed by volumetric titration with $0.1 \mathrm{~N} \mathrm{HCl}$. Chloride $\left(\mathrm{Cl}^{-}\right)$is determined by the solution of mercuric nitrate $\left(\mathrm{HgNO}_{3}^{-}\right)$. The title below the oxygen $\left(\mathrm{O}_{2}\right)$ is determined by $0.2 \mathrm{~N}$ sodium thiosulfate solution $\left(\mathrm{Na}_{2} \mathrm{~S}_{2} \mathrm{O}_{3}\right)$. The dry residue is determined by evaporation at $105^{\circ} \mathrm{C}$ and weighed by balance of precision $10^{-4}$. Turbidity (NTU) is measured by a turbidimeter: HACH brand, Model 2100 N. For metal analyzes, atomic spectrometry absorption is used after acidification of samples with nitric acid (Figure 5).

The microbiological of Maâmora's groundwater is determined by the method of the most probable number (MPN) Rodier [5]. This method is to inoculate using appropriate decimal sample to analyze a series of tubes 


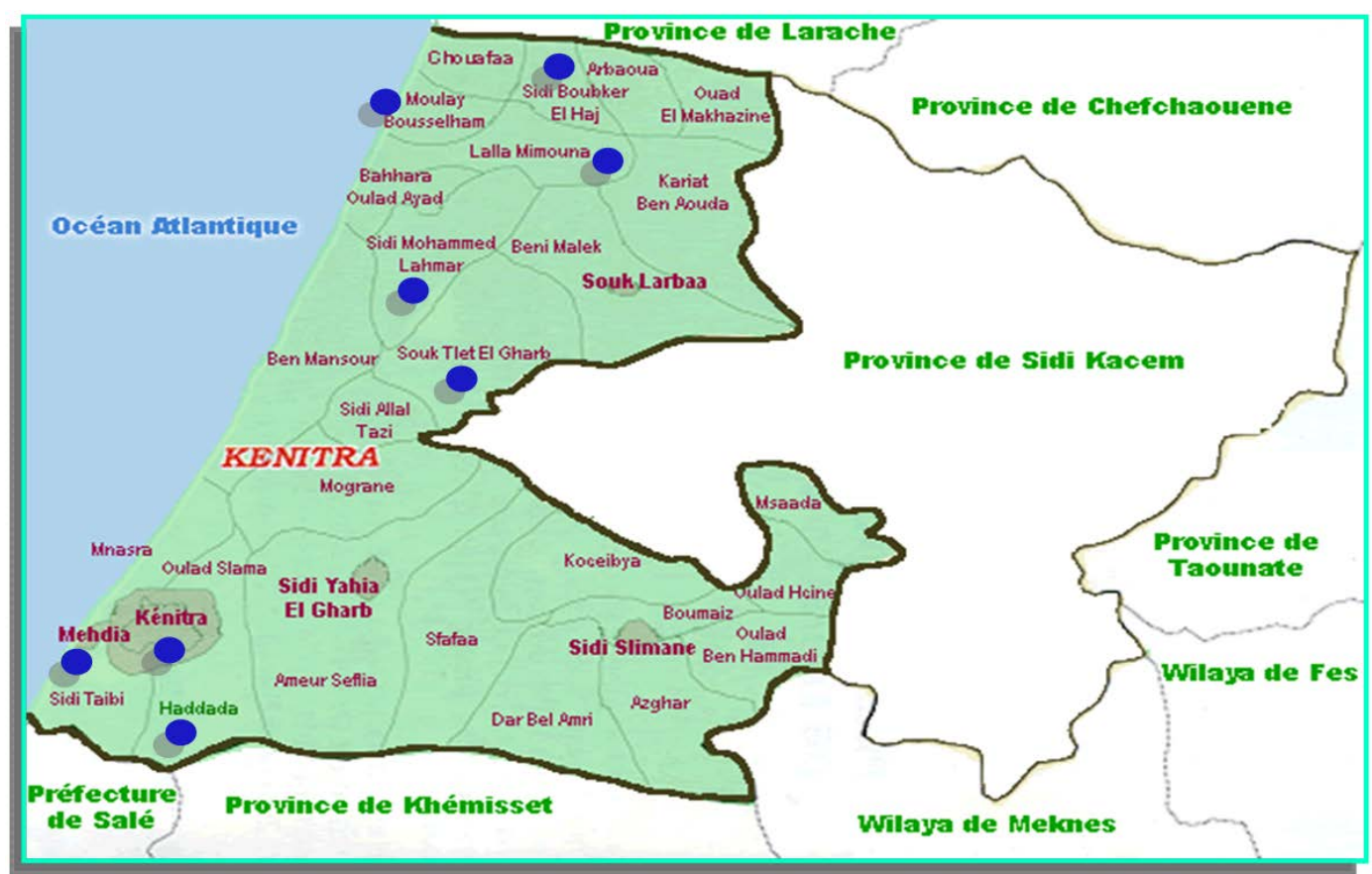

Figure 1. Geographical limits of the Province of Kenitra.

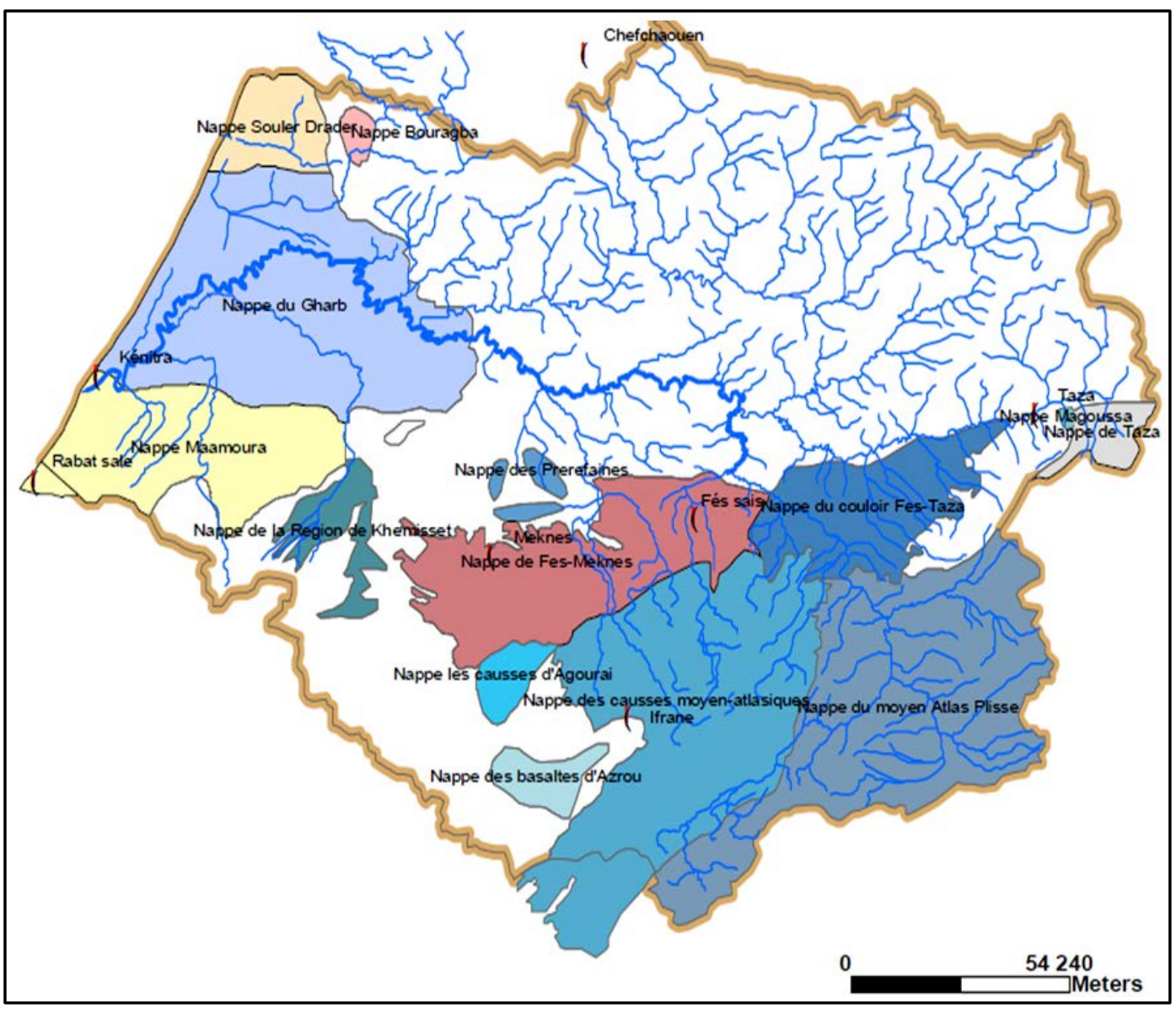

Figure 2. Geographical localization of the study area (Mâamora tablecloth) in Yellow. 
Table 1. Characteristics of studied boreholes and drillings.

\begin{tabular}{|c|c|c|c|}
\hline \multirow{2}{*}{ Laboratories } & \multicolumn{3}{|c|}{ Wells } \\
\hline & Number of Wells & Flows & Localization \\
\hline \multirow{10}{*}{ ONEP } & W1 & 156 & Ain Sbai \\
\hline & W2 & 50 & El Menzeh \\
\hline & W3 & 150 & Ain Arris \\
\hline & W4 & 45 & Ahmed Taleb \\
\hline & W5 & 40 & Ain Khadra \\
\hline & W6 & 100 & Ain Taicha \\
\hline & W7 & 100 & Sidi Taibi \\
\hline & W8 & 40 & Sidi Yahia \\
\hline & W9 & 50 & ElBahraoui \\
\hline & W10 & 50 & Road SoukElarbaa \\
\hline \multirow{5}{*}{ ORMVAG } & W11 & 20 & Oulad Berjal \\
\hline & W12 & 30 & Oulad Berjal \\
\hline & W13 & 15 & Oulad Berjal \\
\hline & W14 & 25 & Oulad Berjal \\
\hline & W15 & 23 & Oulad Berjal \\
\hline \multirow{6}{*}{ University (EER) } & W16 & 37 & Mehdia \\
\hline & W17 & 17 & Bir Rami \\
\hline & W18 & 56 & Mnassra \\
\hline & W19 & 48 & Mnassra \\
\hline & W20 & 28 & Bouknadel \\
\hline & W21 & 22 & Sidi Tayebi \\
\hline \multirow{6}{*}{ RAK } & W22 & 57 & Stadium \\
\hline & W23 & 50 & ElBahraoui \\
\hline & W24 & 108 & Tayebi \\
\hline & W25 & 55 & ElBahraoui \\
\hline & W26 & 46 & ElBahraoui \\
\hline & W27 & 45 & ElBahraoui \\
\hline
\end{tabular}

containing nutrient broth medium for searching the total flora dilutions. After incubation for $24 \mathrm{~h}$ at $37^{\circ} \mathrm{C}$, the tubes with a disorder are considered positive. The assessment of faecal contamination is achieved by the enumeration of faecal coliforms and faecal streptococci. Total coliforms are counted after incubation for $24 \mathrm{~h}$ to 48 $\mathrm{h}$ at $37^{\circ} \mathrm{C}$, the tubes contain the medium broth lactose bromocresol purple and are fitted with a Durham (presumptive test). The positive tubes (lactose fermentation and gas production) are transplanted to a confirmatory test in a selective medium containing bile salts, bile brilliant green broth with a Durham tube, and another tube contains peptone water free indole and then incubated for $24 \mathrm{~h}$ to $48 \mathrm{~h}$ at $44^{\circ} \mathrm{C}$. Gas production in the first and in the second indole is evidenced by the presence of fecal coliforms.

As for streptococci, their research is done on the Rothe medium at $37^{\circ} \mathrm{C}$ for $24 \mathrm{~h}$ (presumptive test). From tubes positive Rothe, a subculture is performed on middle Litsky at $37^{\circ} \mathrm{C}$ for $24 \mathrm{~h}$ (confirmatory test). The results are expressed as number of organisms per $100 \mathrm{ml}$ following statistical table Mac Crady. The results are analyzed by a statistical comparison of the mean test of Duncun [6]. From the $p<0.05$ level, the test is taken as being significant. 


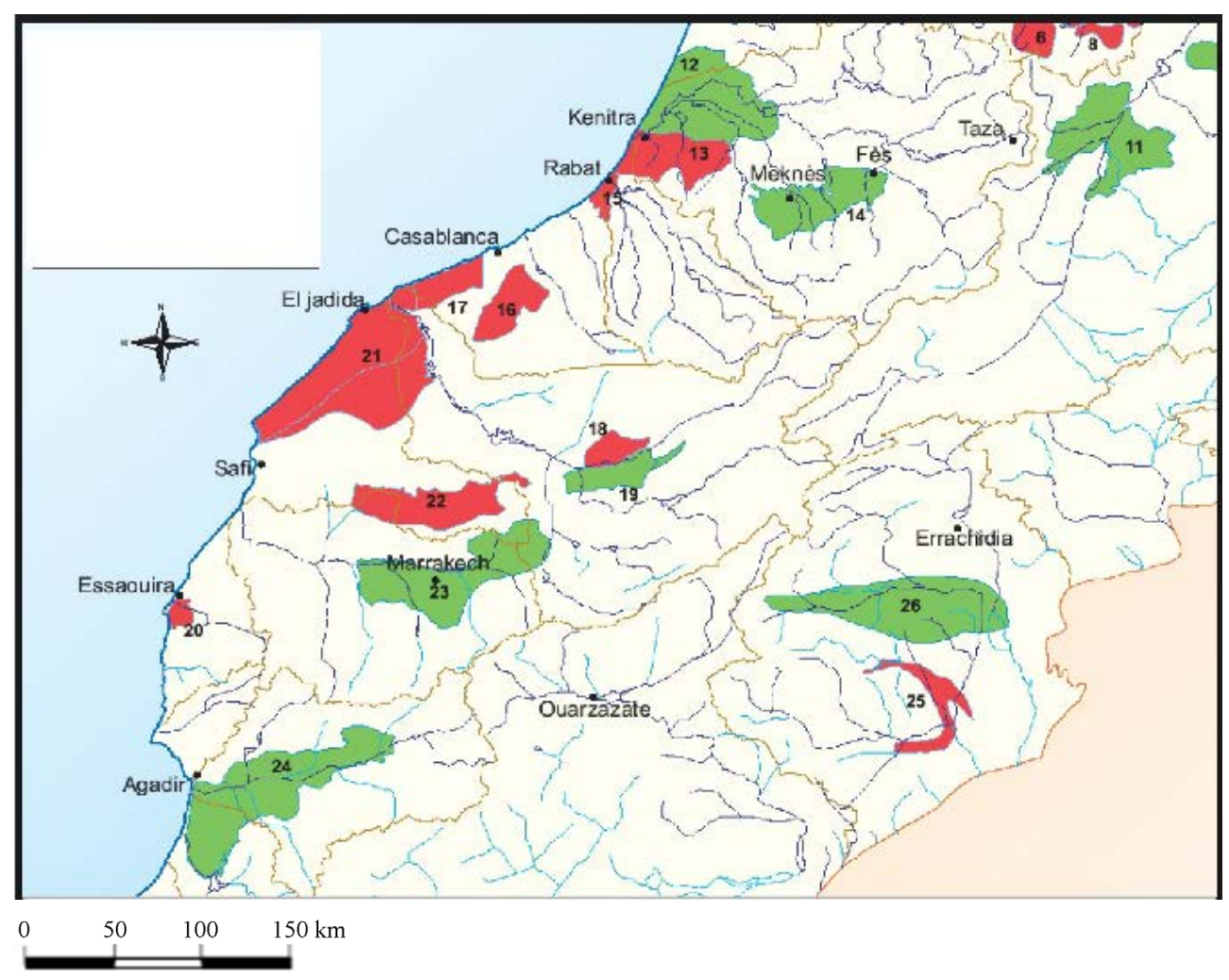

Figure 3. Maâmora’s tablecloth (13) and other aquifers of Morocco.

\section{Results}

The assessment of the physical, chemical (Tables 2-7), metal (Table 8) and bacteriological (Table 10) quality of the Maâmora's water was followed through the analyses of waters collected at the 10 drillings during MarchApril 2010 (ONEP), 6 drillings on March-June 2012 (RAK), 5 wells 2013 (ORMVAG) and 6 wells (EER-Faculty) from January to October 2014.

\subsection{Physical and Chemical Results}

\subsubsection{Temperature}

We note that the temperature values remain almost constant (Table 9) and remain about 19.6 and 21.9. This is due to that groundwater is protected from solar radiation and the atmosphere.

\subsection{2. $\mathrm{pH}$}

The $\mathrm{pH}$ of the water varies in the study from 6.65 to 7.96 (Table 9). The values obtained are close to neutrality, while referring to the Moroccan standards $(6.5<\mathrm{pH}<8.5)$ for drinking water, we note that $100 \%$ of the analyzed waters conform to human consumption. Indeed, the waters of the Maâmora do not require pH adjustment.

\subsubsection{Electrical Conductivity EC}

The conductivity values in our study range from 575 to $3220 \mu \mathrm{S} / \mathrm{cm}$ (Table 9). The maximum allowable value (MAV) is set to $2700 \mu \mathrm{S} / \mathrm{cm}$ according to Moroccan drinking water standards. These values are still stable and below VMA in almost boreholes. But the high value of this parameter in marine adjacent boreholes like Mnassra (3220 $\mu \mathrm{S} / \mathrm{cm}$ ) and Mehdia (3020 $\mu \mathrm{S} / \mathrm{cm})$ is explained by the high concentration of sodium chloride (Table 4 and Table 5) attributed to seawater intrusion.

\subsubsection{Chloride $\mathrm{Cl}^{-}$}

In nature the chlorides are widespread, generally in the form of sodium salts $(\mathrm{NaCl})$ and potassium $(\mathrm{KCl})$ and 

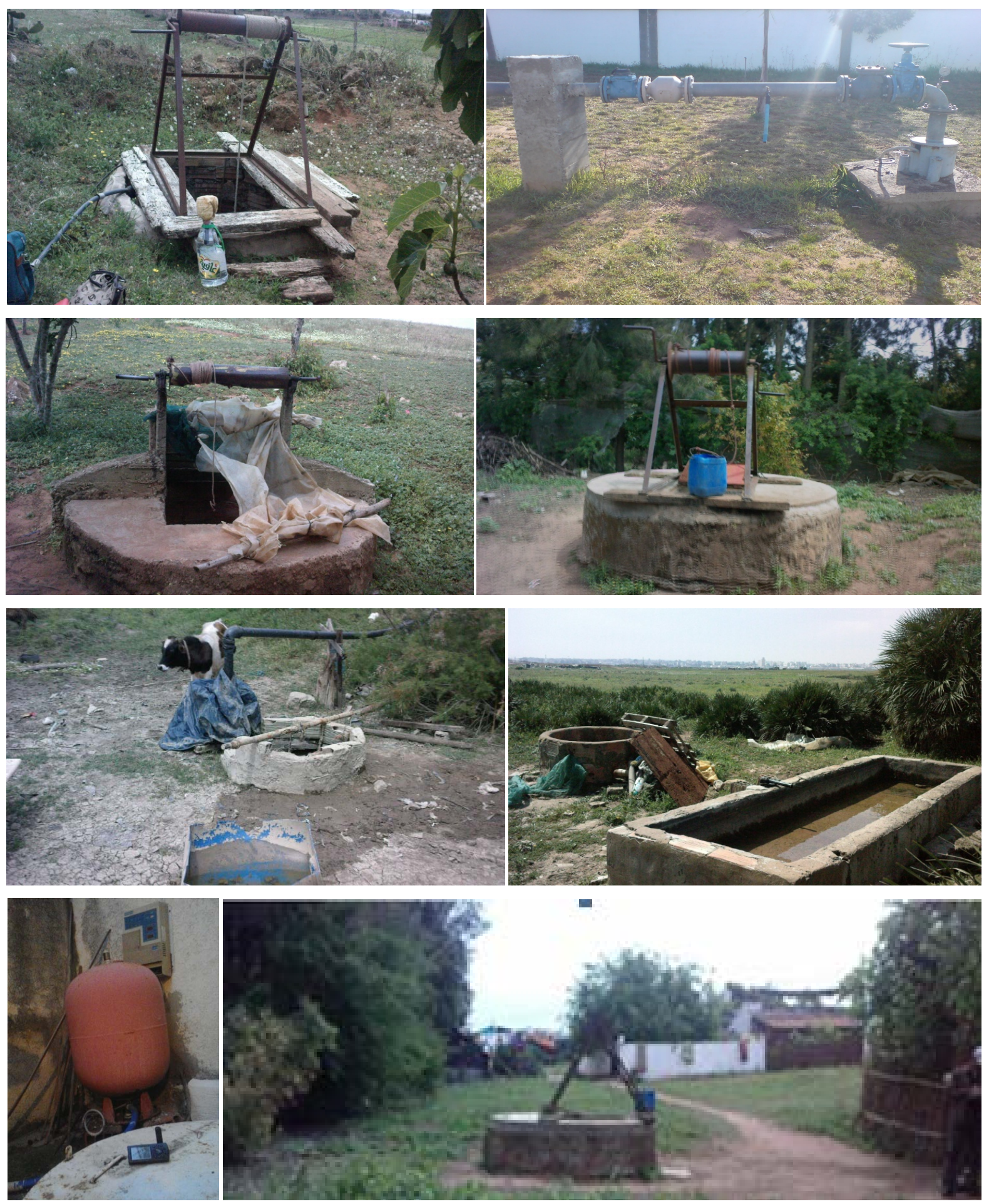

Figure 4. Illustrations of some boreholes and drillings sampled from Kenitra (Mnassra, Bir Rami...).

represent approximately $0.05 \%$ of the lithosphere. The chloride contents range from 81 to $787 \mathrm{mg} / \mathrm{L}$ (Tables 3-5).

\subsubsection{Dissolved Oxygen $\mathrm{O}_{2}$}

Dissolved oxygen varies during the study from 3.32 to $6.72 \mathrm{mg} / \mathrm{L}$ (Table 2). The maximum value is set between $5<\mathrm{O}_{2}<8 \mathrm{mg} \mathrm{O}_{2} / \mathrm{L}$ according to Moroccan standards for drinking water. 


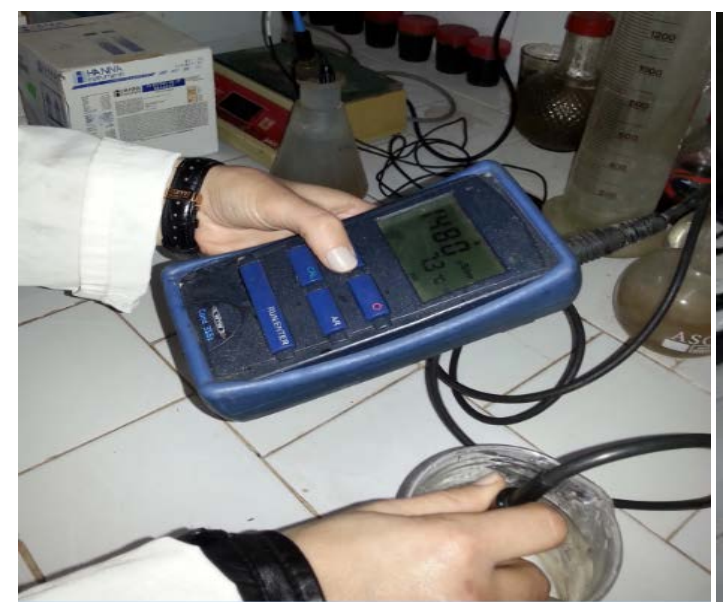

(a)

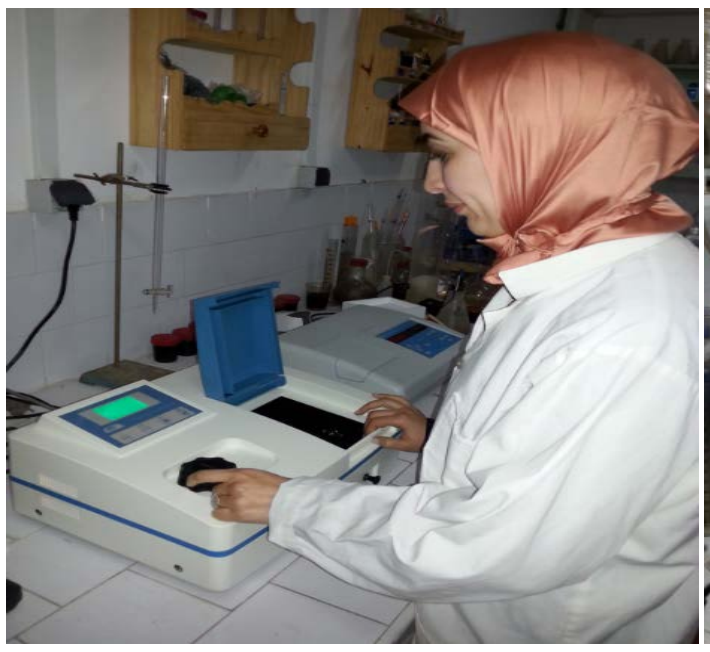

(c)

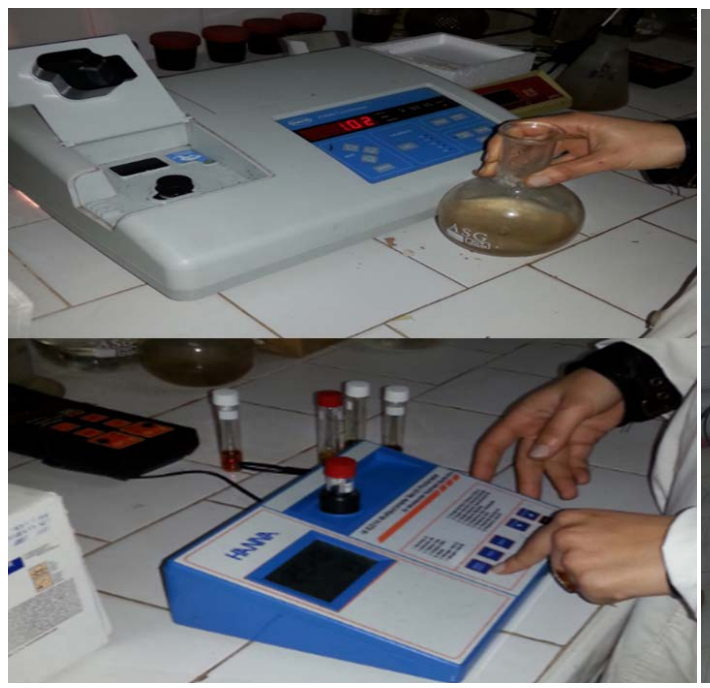

(e)

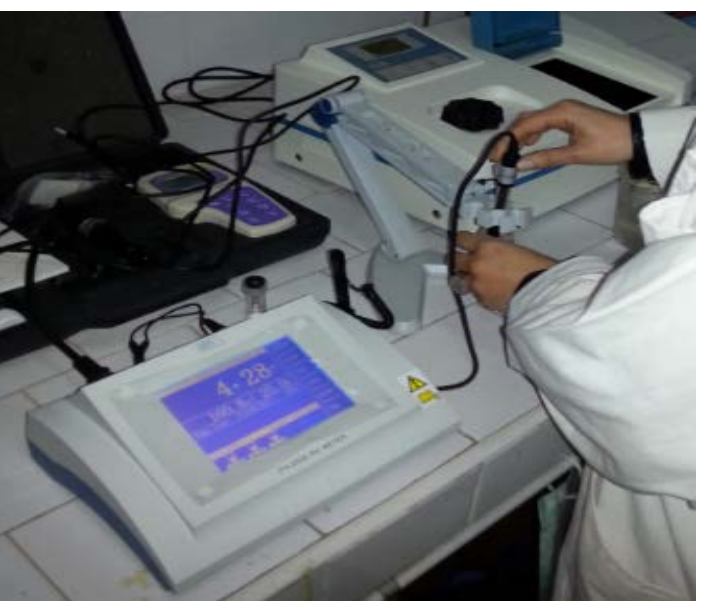

(b)

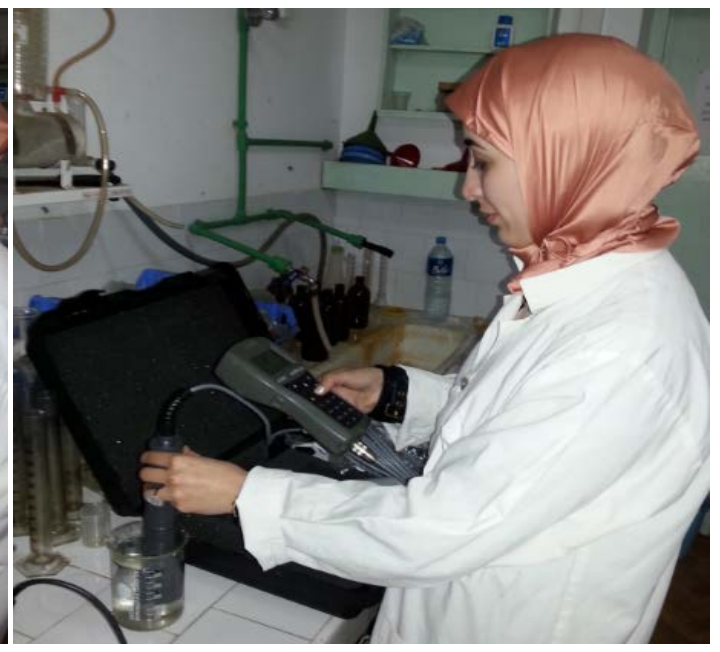

(d)

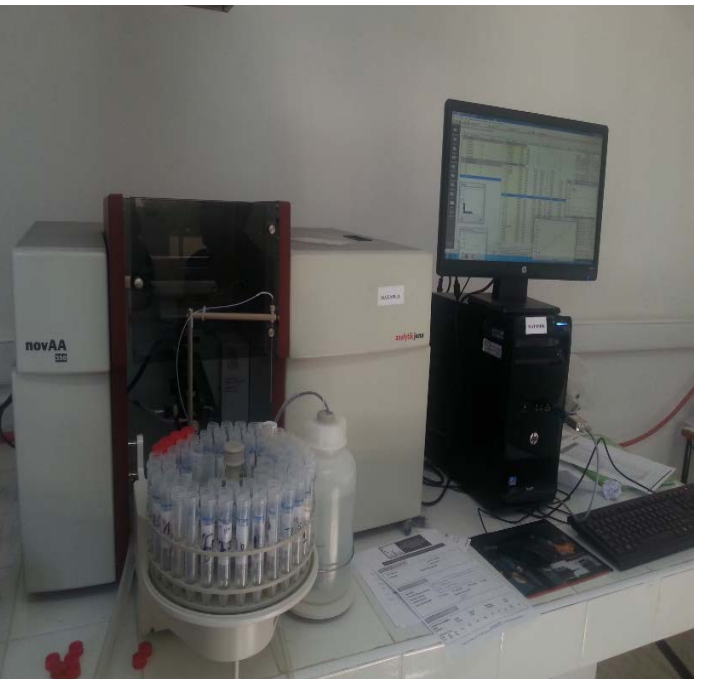

(f)

Figure 5. Methods of analyses of raw water in Laboratory of Environment (Faculty of Science Kenitra). (a) Conductimeter; (b) pH meter; (c) Spectrophotometer; (d) Multiparameter; (e) Turbidimeter and multiparameter; (f) Atomic absorption spectrometry. 
Table 2. Physical and chemical analyses from ONEP drillings (March-April 2010).

\begin{tabular}{|c|c|c|c|c|c|c|c|c|c|}
\hline \multirow{2}{*}{ Boreholes Localizations } & \multicolumn{9}{|c|}{ Physical/Chemicals } \\
\hline & $\mathrm{T}^{\circ} \mathrm{C}$ & $\mathrm{pH}$ & $\mathrm{EC} \mu \mathrm{S} / \mathrm{cm}$ & TDS & $\mathrm{O}_{2}$ & $\mathrm{Ca}^{2+}$ & $\mathrm{Mg}^{2+}$ & $\mathrm{Na}^{+}$ & $\mathrm{K}^{+}$ \\
\hline Saknia-W1 ${ }^{\mathrm{a}}$ & 19.7 & 7.35 & 671 & 346 & 6.72 & 58 & 38 & 62 & 11 \\
\hline El Menzeh-Bir Rami-W2a & 20.1 & 6.86 & 945 & 297 & 6.24 & 102 & 24 & 39.8 & 5.5 \\
\hline Ain Arris-W3 ${ }^{\mathrm{a}}$ & 19.8 & 7.2 & 691 & 418 & 3.38 & 60 & 37 & 89 & 14.7 \\
\hline Ahmed Taleb-W4 ${ }^{\mathrm{a}}$ & 19.6 & 7.16 & 882 & 387 & 6.48 & 98 & 34 & 78 & 12.5 \\
\hline Ain Khadra-W5 $5^{\mathrm{a}}$ & 20 & 7.13 & 736 & 279 & 5.67 & 53 & 35 & 67 & 13 \\
\hline Ain Taicha-W6 ${ }^{\mathrm{a}}$ & 19.9 & 6.8 & 954 & 496 & 4.83 & 156 & 27 & 387 & 4.5 \\
\hline Sidi Taibi-W7 ${ }^{\mathrm{a}}$ & 21.9 & 6.89 & 769 & 407 & 3.32 & 58 & 30 & 85.6 & 13.8 \\
\hline Sidi Yahia-W8 ${ }^{\mathrm{a}}$ & 20 & 7.21 & 754 & 394 & 6.5 & 125 & 27 & 77 & 9.9 \\
\hline ElBahraoui-W9 ${ }^{\mathrm{a}}$ & 21.8 & 7.73 & 575 & 376 & 5.64 & 130 & 35 & 60 & 15 \\
\hline ElBahraoui-W10 ${ }^{\mathrm{a}}$ & 21.4 & 7.45 & 825 & 388 & 4.88 & 99 & 31 & 89 & 17 \\
\hline Saknia-W $1^{\text {b }}$ & 20.4 & 7.2 & 698 & 367 & 6.72 & 63 & 25 & 65 & 15.1 \\
\hline El Menzeh-Bir Rami-W2 ${ }^{\mathrm{b}}$ & 21.2 & 6.65 & 878 & 293 & 6.24 & 98 & 27 & 34.5 & 6.7 \\
\hline Ain Arris-W3 ${ }^{\mathrm{b}}$ & 20.7 & 7.21 & 732 & 440 & 3.38 & 60 & 33 & 89 & 14.8 \\
\hline Ahmed Taleb-W4 ${ }^{\mathrm{b}}$ & 20.3 & 7.2 & 653 & 453 & 6.48 & 110 & 32 & 85 & 13.8 \\
\hline Ain Khadra-W5 $5^{\mathrm{b}}$ & 20.6 & 7.18 & 820 & 263 & 6.35 & 58 & 31 & 48 & 14.2 \\
\hline Ain Taicha-W6 ${ }^{\mathrm{b}}$ & 20.2 & 6.9 & 879 & 514 & 6.2 & 160 & 25 & 386 & 7.5 \\
\hline Sidi Taibi6W7 ${ }^{\mathrm{b}}$ & 20.4 & 6.9 & 765 & 432 & 3.32 & 61 & 32 & 91 & 14.3 \\
\hline Sidi Yahia-W8 ${ }^{\mathrm{b}}$ & 20 & 7.65 & 745 & 489 & 6.5 & 165 & 22 & 125 & 14.5 \\
\hline ElBahraoui-W9 ${ }^{\mathrm{b}}$ & 20.6 & 7.89 & 595 & 449 & 5.64 & 159 & 26 & 111 & 11.8 \\
\hline ElBahraoui-W10 & 20.1 & 7.33 & 835 & 449 & 4.88 & 140 & 28.5 & 113 & 15 \\
\hline
\end{tabular}

${ }^{\mathrm{a}}$ Sample of water on March 2010; ${ }^{\mathrm{b}}$ Sample of water on April 2010.

\subsubsection{Oxidisability $\mathrm{KMnO}_{4}$}

The oxidisability by $\mathrm{KMnO}_{4}$ dissolved varies during the study from 1.0 to $3.2 \mathrm{mg} / \mathrm{L} \mathrm{O}_{2}$ (Table 2). The maximum allowable value of $\mathrm{O}_{2}$ is $5 \mathrm{mg} / \mathrm{L}$ by Moroccan standards for drinking water ONEP [7].

\subsubsection{Turbidity NTU}

Turbidity varies during the study from 0.78 to 3.75 NTU, the maximum value is 5 NTU by Moroccan standards for drinking water. We find that $100 \%$ of the analyzed waters have turbidity levels below the maximum value and that are consistent with Moroccan standards as these groundwater have natural filtration in the soil.

\subsubsection{Dry Residue}

During our study, the dry residues values range from 0.0112 to $0.1246 \mathrm{mg} / \mathrm{L}$. The maximum value is set at 0.5 $\mathrm{mg} / \mathrm{L}$ according to Moroccan standards of water potability. So these values are still lower than the maximum permissible value.

\subsubsection{Alkalinity $\mathrm{HCO}_{3}^{-}$}

The TAC assay is the ions $\mathrm{HO}^{-}, \mathrm{HCO}_{3}^{-}$and $\mathrm{CO}_{3}^{2-}$ present in the water, that is to say all of the basic species present. The alkali strength is a measurement of the water tenure of free carbonate and caustic alkali. TAC water varies during the study from 4 to $6.2 \mathrm{meq} / \mathrm{L}$ (Table 3). According to Moroccan standards of potability of water 
Table 3. Physical and chemical analyzes from ONEP drillings (March-April 2010).

\begin{tabular}{|c|c|c|c|c|c|c|c|c|c|c|}
\hline \multirow{2}{*}{ Boreholes Localizations } & \multicolumn{10}{|c|}{ Physical/Chemicals } \\
\hline & $\mathrm{HCO}_{3}^{-}$ & $\mathrm{CO}_{3}^{2-}$ & $\mathrm{F}^{-}$ & $\mathrm{Cl}^{-}$ & $\mathrm{SO}_{4}^{2-}$ & $\mathrm{NO}_{2}^{-}$ & $\mathrm{NO}_{3}^{-}$ & $\mathrm{SiO}_{2}$ & $\mathrm{NH}_{4}^{+}$ & TAC \\
\hline Saknia-W1 $1^{\text {a }}$ & 234 & 0 & 0.2 & 81.7 & 19.7 & 0 & 48 & 22.1 & 0 & 4.2 \\
\hline El Menzeh-Bir Rami-W2a & 258 & 0 & 0.21 & 103 & 20.1 & 0 & 2.02 & 0.25 & 0.11 & 5 \\
\hline Ain Arris-W3 ${ }^{\mathrm{a}}$ & 243 & 0 & 0.18 & 195 & 19.8 & 0 & 1.46 & 0.47 & 0.01 & 5.3 \\
\hline Ahmed Taleb-W4 & 261 & 0 & 0.23 & 153 & 19.6 & 0 & 32.2 & 0.73 & 0.31 & 4 \\
\hline Ain Khadra-W5 ${ }^{\mathrm{a}}$ & 239 & 0 & 0.2 & 85.2 & 20 & 0 & 4.56 & 0.83 & 0.12 & 4.3 \\
\hline Ain Taicha-W6 $6^{\mathrm{a}}$ & 389 & 0 & 0.25 & 213 & 19.9 & 0 & 36.5 & 0.35 & 0.23 & 4.5 \\
\hline Sidi Taibi-W7 ${ }^{\mathrm{a}}$ & 250 & 0 & 0.19 & 153 & 15 & 0.02 & 51.6 & 0.5 & 0.05 & 5.4 \\
\hline Sidi Yahia-W8 ${ }^{\mathrm{a}}$ & 356 & 0 & 0.24 & 114 & 13.7 & 0.02 & 26.2 & 0.91 & 0.04 & 4.9 \\
\hline ElBahraoui-W9 ${ }^{\mathrm{a}}$ & 343 & 0 & 0.2 & 92.3 & 14.3 & 0.01 & 4.34 & 19.5 & 0.04 & 5.4 \\
\hline ElBahraoui-W10 ${ }^{\mathrm{a}}$ & 353 & 0 & 0.26 & 135 & 11.7 & 0.05 & 5.13 & 0.35 & 0.04 & 6.2 \\
\hline Saknia-W1 ${ }^{\mathrm{b}}$ & 229 & 0 & 0.2 & 107 & 20.4 & 0 & 45.7 & 21 & 0.01 & 4.3 \\
\hline El Menzeh-Bir Rami-W2 ${ }^{b}$ & 245 & 0 & 0.21 & 103 & 21.2 & 0 & 2.21 & 0.24 & 0.13 & 5.4 \\
\hline Ain Arris-W3 ${ }^{b}$ & 247 & 0 & 0.18 & 220 & 20.7 & 0 & 1.25 & 0.5 & 0.12 & 5 \\
\hline Ahmed Taleb-W4 ${ }^{\mathrm{b}}$ & 255 & 0 & 0.23 & 206 & 20.3 & 0 & 33.3 & 0.71 & 0.01 & 4.6 \\
\hline Ain Khadra-W5 ${ }^{\mathrm{b}}$ & 238 & 0 & 0.21 & 85.2 & 20.6 & 0 & 4.73 & 0.82 & 0.1 & 4.4 \\
\hline Ain Taicha-W6 $6^{\mathrm{b}}$ & 397 & 0 & 0.23 & 238 & 20.2 & 0 & 37.2 & 0.36 & 0.35 & 5.6 \\
\hline Sidi Taibi-W7 & 261 & 0 & 0.19 & 167 & 14.6 & 0.03 & 51 & 0.47 & 0.04 & 5.5 \\
\hline Sidi Yahia-W8b & 380 & 0 & 0.24 & 124 & 14.3 & 0.01 & 22.5 & 0.93 & 0.04 & 4.9 \\
\hline ElBahraoui-W9 ${ }^{\mathrm{b}}$ & 395 & 0 & 0.2 & 95.9 & 15.4 & 0.01 & 4.54 & 19.5 & 0.04 & 5.4 \\
\hline ElBahraoui-W10 & 378 & 0 & 0.26 & 135 & 11.6 & 0.06 & 4.73 & 0.38 & 0.04 & 6 \\
\hline
\end{tabular}

${ }^{\mathrm{a}}$ Sample of water on March 2010. ${ }^{\mathrm{b}}$ Sample of water on April 2010.

Table 4. Physical and chemical analyzes from Lab. ORMVAG (February-June 2013).

\begin{tabular}{|c|c|c|c|c|c|c|c|c|c|c|}
\hline \multirow{2}{*}{ Boreholes Localizations } & \multicolumn{10}{|c|}{ Physical/Chemicals ${ }^{a}$} \\
\hline & $\mathrm{pH}$ & $\mathrm{CE}$ & $\mathrm{Ca}^{2+}$ & $\mathrm{Mg}^{2+}$ & $\mathrm{Na}^{+}$ & $\mathrm{K}^{+}$ & $\mathrm{HCO}_{3}^{-}$ & $\mathrm{NO}_{3}^{-}$ & $\mathrm{Cl}^{-}$ & $\mathrm{SO}_{4}^{2-}$ \\
\hline Borehole W11 Mnassra & 7.67 & 3220 & 86 & 68.64 & 2336.8 & 11.31 & 63.44 & 18.6 & 787.39 & 312 \\
\hline Borehole W12 Mnassra & 7.96 & 2180 & 106 & 49.68 & 1610.92 & 5.07 & 47.58 & 16.12 & 541.73 & 292 \\
\hline Borehole W13 Bir Rami & 7.8 & 2540 & 119.2 & 79.2 & 1591.6 & 8.58 & 56.12 & 6.82 & 577.94 & 398.4 \\
\hline Borehole W14 Mehdia & 7.79 & 3020 & 113 & 65.76 & 2072.3 & 9.36 & 50.02 & 8.06 & 669.35 & 489.6 \\
\hline Borehole W15 Sidi Tayebi & 7.71 & 2310 & 115.2 & 52.08 & 1644.5 & 12.09 & 51.24 & 27.9 & 522.56 & 302.4 \\
\hline
\end{tabular}

${ }^{\mathrm{a}}$ Sample of water on February-June 2013.

the maximum value is $50 \mathrm{meq} / \mathrm{L}$. $\mathrm{HCO}_{3}^{-}$water varies during the study from 47.58 to $397 \mathrm{mg} / \mathrm{L}$ (Table 9). $\mathrm{HCO}_{3}^{-}$is an indicator of the presence of ions carbonates, bicarbonates, hydroxides hardness of drinking water factor.

\subsubsection{Total Hardness TH}

The total hardness TH of water varies during the study from $28.5 \mathrm{meq} / \mathrm{L}$ to $55 \mathrm{meq} / \mathrm{L}$ (Table 9 ). The maximum 
Table 5. Physical and chemical analyzes from Lab. EER, University Ibn Tofail (January-October 2014).

\begin{tabular}{cccccccccccc}
\hline & \multicolumn{7}{c}{ Physical/Chemicals } \\
\cline { 2 - 10 } Boreholes Localizations & $\mathrm{pH}$ & $\mathrm{CE}$ & $\mathrm{Ca}^{2+}$ & $\mathrm{Mg}^{2+}$ & $\mathrm{Na}^{+}$ & $\mathrm{K}^{+}$ & $\mathrm{HCO}_{3}^{-}$ & $\mathrm{NO}_{3}^{-}$ & $\mathrm{Cl}^{-}$ & $\mathrm{SO}_{4}^{2-}$ \\
\hline Borehole W16 Mnassra & 7.61 & 2000 & 122 & 26.64 & 358.8 & 0.39 & 324.52 & 4.34 & 492.1 & 216.8 \\
Borehole W17 Mnassra & 7.75 & 1140 & 71.6 & 31.2 & 133.4 & 15.99 & 253.76 & 28.52 & 210.7 & 36.4 \\
Borehole W18 Bir Rami & 7.45 & 990 & 111.6 & 27.84 & 46 & 7.8 & 259.86 & 210.8 & 172.2 & 28.4 \\
Borehole W19 Mehdia & 7.63 & 2410 & 111.6 & 12.72 & 391 & 1.17 & 391.62 & 21.08 & 620.9 & 173.6 \\
Borehole W20 Sidi Tayebi & 7.78 & 1130 & 63.6 & 39.12 & 98.9 & 15.6 & 247.66 & 11.16 & 256.2 & 20.8 \\
Borehole W21 Bouknadel & 7.48 & 1520 & 187.2 & 20.16 & 135.7 & 1.56 & 328.18 & 163.68 & 298.9 & 82.4 \\
\hline
\end{tabular}

${ }^{\mathrm{a}}$ Sample of water on January-October 2014.

Table 6. Physical and chemical analyzes from Lab. EER, University Ibn Tofail.

\begin{tabular}{cccc}
\hline & \multicolumn{2}{c}{ Physical/Chemicals $^{\mathrm{a}}$} \\
\cline { 2 - 4 } Boreholes Localizations & $\mathrm{NH}_{4}^{+}$ & $\mathrm{CO}_{3}^{2-}$ & $\mathrm{TH}$ \\
\hline Borehole W16 Mnassra & 3.42 & 0 & 42 \\
Borehole W17 Mnassra & 4.5 & 0 & 31 \\
Borehole W18 Bir Rami & 4.32 & 0 & 45 \\
Borehole W19 Mehdia & 5.94 & 0 & 32 \\
Borehole W20 Sidi Tayebi & 3.42 & 0 & 55 \\
\hline
\end{tabular}

${ }^{\mathrm{a}}$ Sample of water on January-October 2014.

Table 7. Physical and chemical analyzes from Lab. RAK (March-June 2012).

\begin{tabular}{|c|c|c|c|c|c|c|c|c|}
\hline \multirow{2}{*}{ Boreholes Localizations } & \multicolumn{8}{|c|}{ Physical/Chemicals $^{\text {a }}$} \\
\hline & $\mathrm{pH}$ & $\mathrm{EC}$ & $\mathrm{NH}_{4}^{+}$ & $\mathrm{NO}_{3}^{-}$ & $\mathrm{SO}_{4}^{2-}$ & $\mathrm{CO}_{3}^{2-}$ & $\mathrm{Mg}^{2+}$ & $\mathrm{TH}$ \\
\hline Borehole W22 Mnassra & 6.94 & 831 & 0.002 & 91.09 & 16.2 & 0 & 15.2 & 36.7 \\
\hline Borehole W23 Mnassra & 6.84 & 743 & 0.002 & 39.81 & 6.85 & 0 & 13.4 & 33.9 \\
\hline Borehole W24 Bir Rami & 6.99 & 724 & 0.002 & 10.71 & 6.17 & 0 & 20.7 & 32 \\
\hline Borehole W25 Mehdia & 7 & 626 & 0.002 & 23.95 & 4.18 & 0 & 12.2 & 28.5 \\
\hline Borehole W26 Sidi Tayebi & 6.96 & 605 & 0.002 & 19.14 & 2.3 & 0 & 13.4 & 29 \\
\hline Borehole W27 Bouknadel & 7.05 & 680 & 0.002 & 14.05 & 2.3 & 0 & 12.2 & 31.2 \\
\hline
\end{tabular}

${ }^{\mathrm{a}}$ Sample of water on March-June 2012.

for Moroccan standards of potability is the value $50 \mathrm{meq} / \mathrm{L}$. TH is a factor indicating the presence of magnesium and calcium ions. The release by rocks containing divalent metals $\left(\mathrm{Mg}^{2+}, \mathrm{Ca}^{2+}\right)$ is responsible for this hardness.

\subsubsection{Nitrates $\mathrm{NO}_{3}^{-}$}

The nitrate content varies during the study from 1.25 to $210.8 \mathrm{mg} / \mathrm{L}$ (Table 9 ). According to Moroccan standards of potability of water ONEP [7], the maximum value is set at $50 \mathrm{mg} / \mathrm{l}$. Although nitrates have no direct toxic effects except at high doses, the fact that they can give birth to nitrites which lead to toxicity. Nitrate levels are high in boreholes W7, W18, W21 and W22 (Mnassra, Sidi Tayebi, Bouknadel, Bir Rami) which exceed the Moroccan standards. 
Table 8. Concentration of metalic elements in Maâmora's groundwaters.

\begin{tabular}{ccccccc}
\hline \multirow{2}{*}{ Geography } & \multicolumn{7}{c}{ Metals $(\mu \mathrm{g} / \mathrm{L})^{\mathrm{a}}$} \\
\cline { 2 - 6 } & Lead & Zinc & Nickel & Cadmium & Copper & Iron \\
\hline Borehole W16 Mnassra & 45.4 & 7 & 69.8 & $<1.2$ & 38.5 & 79.2 \\
Borehole W17 Mnassra & 63.4 & 36.7 & 55 & $<1.2$ & 45.6 & 50.9 \\
Borehole W18 Bir Rami & 55.7 & 2204 & 77.2 & $<1.2$ & 27.3 & 50.6 \\
Borehole W19 Mehdia & 69.4 & 1427 & 78.9 & $<1.2$ & 72.6 & 100.1 \\
Borehole W20 Sidi Tayebi & 60.4 & 28.93 & 70.1 & $<1.2$ & 26.8 & 42.2 \\
Borehole W21 Bouknadel & 185.6 & 28.9 & 2.9 & $<1.2$ & 30.6 & 187.3 \\
Mean & 79.98 & 622.1 & 58.98 & $<1.2$ & 40.23 & 85.05 \\
Morocco Standards & $50 / 25 / 10$ & 3000 & 20 & 3 & 2000 & 300 \\
\hline
\end{tabular}

${ }^{\mathrm{a}}$ Metal analyses were done at Faculty of Sciences Laboratory, Kenitra, Morocco.

Table 9. Statistical of all analyzes of Maâmora’s groundwaters.

\begin{tabular}{|c|c|c|c|c|c|}
\hline \multirow{2}{*}{ Parameters } & \multicolumn{5}{|c|}{ Physical and Chemical Analyses ${ }^{a}$} \\
\hline & Sample Size & Minima & Maxima & Mean & SD \\
\hline $\mathrm{T}^{\circ} \mathrm{C}$ & 37 & 19.60 & 21.90 & 20.43 & 0.48 \\
\hline $\mathrm{pH}$ & 37 & 6.65 & 7.96 & 7.30 & 0.36 \\
\hline $\mathrm{EC} \mu \mathrm{S} / \mathrm{cm}$ & 37 & 575.00 & 3220.00 & 1137.05 & 725.19 \\
\hline $\mathrm{NH}_{4}^{+} \quad \mathrm{mg} / \mathrm{L}$ & 37 & 0.00 & 5.94 & 1.09 & 1.76 \\
\hline $\mathrm{NO}_{3}^{-} \mathrm{mg} / \mathrm{L}$ & 37 & 1.25 & 210.80 & 30.67 & 42.91 \\
\hline $\mathrm{Cl}^{-} \mathrm{mg} / \mathrm{L}$ & 37 & 81.70 & 787.39 & 256.65 & 184.48 \\
\hline $\mathrm{SO}_{4}^{2-} \mathrm{mg} / \mathrm{L}$ & 37 & 2.30 & 489.60 & 74.16 & 124.97 \\
\hline $\mathrm{HCO}_{3}^{-} \mathrm{mg} / \mathrm{L}$ & 37 & 47.58 & 397.00 & 258.87 & 98.51 \\
\hline $\mathrm{CO}_{3}^{2-} \mathrm{mg} / \mathrm{L}$ & 37 & 0.00 & 0.00 & 0.00 & 0.00 \\
\hline $\mathrm{TH}{ }^{\circ} \mathrm{F}$ & 37 & 28.50 & 55.00 & 36.27 & 4.33 \\
\hline $\mathrm{Ca}^{2+} \mathrm{mg} / \mathrm{L}$ & 37 & 53.00 & 187.20 & 103.87 & 34.27 \\
\hline $\mathrm{Mg}^{2+} \mathrm{mg} / \mathrm{L}$ & 37 & 12.20 & 79.20 & 31.34 & 15.25 \\
\hline $\mathrm{Na}^{+} \mathrm{mg} / \mathrm{L}$ & 37 & 34.50 & 2336.80 & 406.51 & 605.85 \\
\hline $\mathrm{K}^{+} \mathrm{mg} / \mathrm{L}$ & 37 & 0.39 & 17.00 & 10.76 & 4.31 \\
\hline TDS mg/L & 37 & 263.00 & 514.00 & 396.85 & 52.95 \\
\hline $\mathrm{O}_{2} \mathrm{mg} / \mathrm{L}$ & 37 & 3.32 & 6.72 & 5.47 & 0.89 \\
\hline $\mathrm{F}^{-} \mathrm{mg} / \mathrm{L}$ & 37 & 0.18 & 0.26 & 0.21 & 0.02 \\
\hline $\mathrm{SiO}_{2} \mathrm{mg} / \mathrm{L}$ & 37 & 0.24 & 22.10 & 4.54 & 5.96 \\
\hline TAC & 37 & 4.00 & 6.20 & 5.01 & 0.44 \\
\hline
\end{tabular}

${ }^{\mathrm{a}}$ Mean of all samples.

\subsubsection{Nitrites $\mathrm{NO}_{2}^{-}$}

The nitrite content varies during the study from 0.00 to $0.06 \mathrm{mg} / \mathrm{L}$ (Table 3). The nitrite remains below of VMA set at $0.5 \mathrm{mg} / \mathrm{L}$ according to Moroccan standards ONEP [7].

\subsubsection{Ammonia $\mathrm{NH}_{4}^{+}$}

In our study the ammonium values are from 0.00 to $5.94 \mathrm{mg} / \mathrm{L}$ (Table 3 and Table 6). The maximum value is set at $0.5 \mathrm{mg} / \mathrm{L}$ according to Moroccan standards of potability. 
3.1.14. Sulfate $\mathrm{SO}_{4}^{2-}$

Sulfate varies during the study between 2.3 and $489.6 \mathrm{mg} / \mathrm{L}$ (Table 9). The maximum value is set at $400 \mathrm{mg} / \mathrm{L}$ by Moroccan standards of potability of water. So the values are still well below the maximum allowable value. This can be justified by the presence of very low sulfate levels in the soil and groundwater in the study area ONEP [7].

\subsubsection{Silicate $\mathrm{SiO}_{2}$}

In this field survey, the values of silicate range from 0.24 and $22.1 \mathrm{mg} / \mathrm{L}$ (Table 3). The maximum value is 100 $\mathrm{mg} / \mathrm{L}$ according to Moroccan standards of potability.

\subsection{Metals Results}

During our study of fluoride the values range from 0.18 and $0.26 \mathrm{mg} / \mathrm{L}$ (Table 3). The maximum value is fixed at $1.5 \mathrm{mg} / \mathrm{L}$ by Moroccan standards of potability.

\subsubsection{Boron $\mathrm{B}^{3+}$}

Boron varies during the study between 0.00 and $0.026 \mathrm{mg} / \mathrm{L}$. The maximum value is set at $0.3 \mathrm{mg} / \mathrm{L}$ according to Moroccan standards of potability. Therefore these values are still well below the authorized maximum value.

\subsubsection{Fluoride $\mathrm{F}^{-}$}

During our study of fluoride the values range from 0.18 and $0.26 \mathrm{mg} / \mathrm{L}$ (Table 3). The maximum value is fixed at $1.5 \mathrm{mg} / \mathrm{L}$ by Moroccan standards of potability.

\subsubsection{Lead $\mathrm{Pb}^{2-}$}

The concentration of lead ranges from 0.0454 to $0.185 \mathrm{mg} / \mathrm{L}(45.4$ to $185.6 \mu \mathrm{g} / \mathrm{L})$. The highest values are recorded in Bouknadel (Table 8). Called the maximum value of $50 \mu \mathrm{g} / \mathrm{L}$ will be applied until 2010 from that date, the VMA is $25 \mu \mathrm{g} / \mathrm{L}$ and will be taxable until 2015. Beyond 2015, the maximum value allowed to comply will be $10 \mu \mathrm{g} / \mathrm{L}$.

\subsubsection{Zinc $\mathrm{Zn}^{2+}$}

The concentrations of zinc vary from 0.007 to $2.204 \mathrm{mg} / \mathrm{L}$ (7 to $2204 \mu \mathrm{g} / \mathrm{L}$ ). The highest values are recorded in Bir Rami and Mehdia (Table 8). The standard is set at $3000 \mu \mathrm{g} / \mathrm{L}$ (VMA). All the values recorded in the Mâamora's wells are lower than Moroccan standard. In Mâamora the average $622 \mu \mathrm{g} / \mathrm{L}$ remains far below the norm and not a problem for the consumption of these waters.

\subsubsection{Nickel $\mathrm{Ni}^{2+}$}

The nickel concentrations range from 0.0029 to $0.0789 \mathrm{mg} / \mathrm{L}(2.9$ to $78.9 \mu \mathrm{g} / \mathrm{L})$. The lowest values are recorded in Bouknadel (Table 8). The standard is set at $20 \mu \mathrm{g} / \mathrm{L}$ (VMA). Almost all the values stored in the wells of the Mâamora exceed this Moroccan standard. In Mâamora averaging $58.98 \mu \mathrm{g} / \mathrm{L}$ is much greater than the standard and poses a serious problem for the consumption of water from the Mâamora's groundwater.

\subsubsection{Cadmium $\mathrm{Cd}^{2+}$}

The cadmium concentrations remain below the limit of flame spectrometer detection $0.0012 \mathrm{mg} / \mathrm{L}(1.2 \mu \mathrm{g} / \mathrm{L})$. The standard is set at $3 \mu \mathrm{g} / \mathrm{L}$ (VMA). So all values stored in the wells of the tablecloth Mâamora do not exceed the Moroccan standard (Table 8 ) and are not problems for the consumption of these waters.

\subsubsection{Copper $\mathrm{Cu}^{2+}$}

In the aquifer Mâamora, the concentration of copper ranges from 26.8 to $72.6 \mu \mathrm{g} / \mathrm{L}$. The highest values are recorded in Mehdia (Table 8). The Moroccan standard is set at $2000 \mu \mathrm{g} / \mathrm{L}$ (VMA). The averaging $40.23 \mu \mathrm{g} / \mathrm{L}$ and all the recorded values in the wells of the Mâamora's aquifer are far below the norm and the consumption of these waters poses no problem.

\subsubsection{Iron $\mathrm{Fe}^{2+}$}

Iron concentrations vary from 0.0422 to $0.1873 \mathrm{mg} / \mathrm{L}$ (42.2 to $187.3 \mu \mathrm{g} / \mathrm{L})$. The highest values are recorded at 
Bouknadel (Table 8). The standard is set at $0.3 \mathrm{mg} / \mathrm{L}(\mathrm{VMA})(300 \mu \mathrm{g} / \mathrm{L})$. All values recorded in the wells of the tablecloth Mâamora remain below the Moroccan standard. In Mâamora's aquifer the Iron average of $85.05 \mu \mathrm{g} / \mathrm{L}$ is below standard and do not pose a problem for the consumption of these waters. We note, however, that the concentration of iron in Bouknal's boreholes is very high $(187.3 \mathrm{mg} / \mathrm{L})$ and may pose a long-term problem due to bioaccumulation through the food chain and direct way.

\subsection{Bacterial Results}

Bacteriological analyses of water from 6 wells (Table 10) studied reveal that there is a lack of contamination by total coliforms, faecal coliforms and faecal streptococci. By against contamination is noted by the total germs at $22^{\circ} \mathrm{C}$ and $37^{\circ} \mathrm{C}$. This is consistent with the Moroccan standards and guidance of ONEP [7]. The total lack of bacteria contamination is attributed to the fact that the modern boreholes and their catchment areas are protected against traditional wells that are contaminated.

\section{Discussion}

The piper diagram (Figure 6) has allowed us to define the hydrochimic and chemical facies of Maâmora's tablecloth waters. The piper diagram shows that 27 wells in the Maâmora's are very heterogeneous and are classified in the following chemical facies:

- chloride, sulphate, Calcium and magnesium;

- chloride, Sodium and potassium or sodium sulphate;

- bicarbonate calcium and magnesium.

Based on the results, the temperature, $\mathrm{pH}$, nitrite, ammonia nitrogen, sulfates and oxidizable materials recorded values below the recommended standards REEM [1] and also approved by (Table 11) the World Health Organization [3]. The electrical conductivity, chloride and bicarbonate $\left(\mathrm{HCO}_{3}^{-}\right)$recorded respective averages $1137.05 \mu \mathrm{S} / \mathrm{cm}, 256.65 \mathrm{mg} / \mathrm{L}$ and $258.87 \mathrm{mg} / \mathrm{L}(6.1 \mathrm{meq} / \mathrm{L})$. We find that these parameters have high values at the wells W6, W11, W14 and W19. The waters of Maâmora are further characterized by a particularly high level of total hardness wells W19 (Mehdia) and W21 (Bouknadel) respectively 42 and 55 meq/L.

\section{Piper diagram}

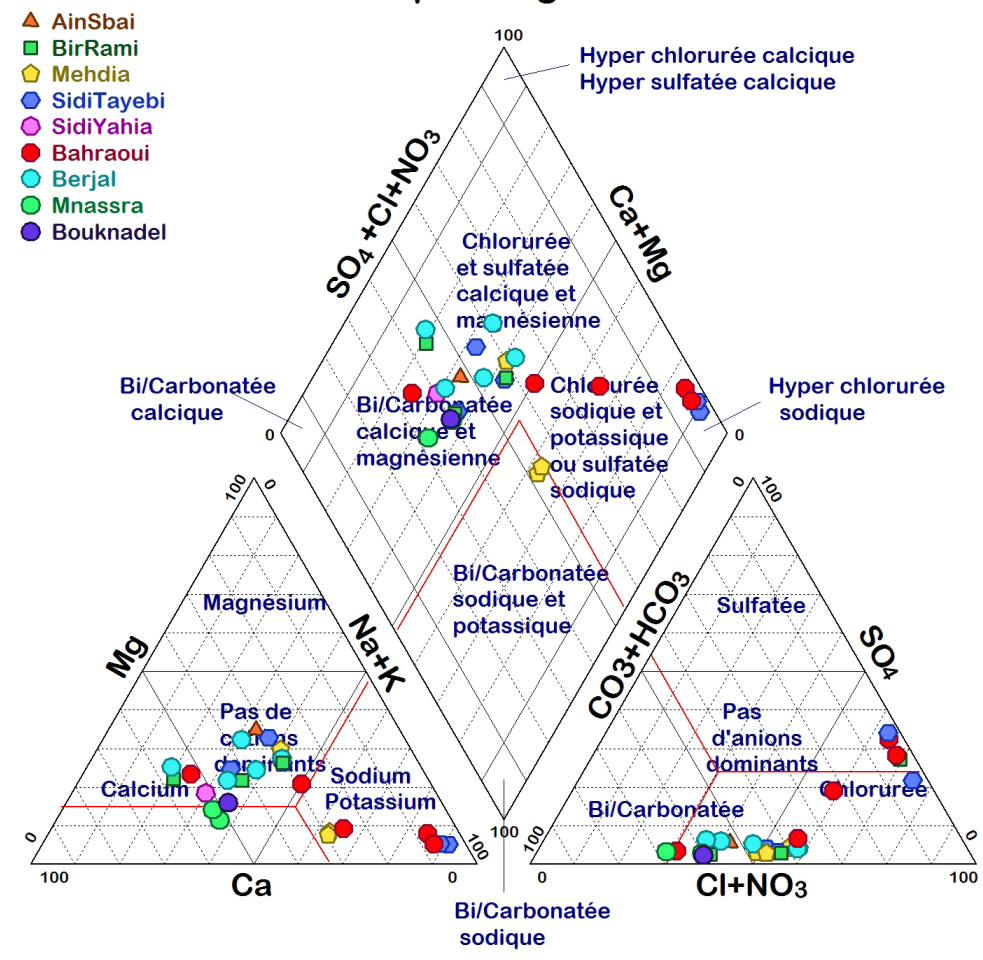

Figure 6. Hydrochemical of Maâmora’s groundwater. 
Table 10. Bacterial analyzes in Maâmora’s groundwaters ${ }^{\mathrm{a}}$.

\begin{tabular}{|c|c|c|c|c|c|}
\hline \multirow{2}{*}{ Geography } & \multicolumn{5}{|c|}{ Bacterial (UFC) ${ }^{b}$} \\
\hline & CT & $\mathrm{CF}$ & $\mathrm{GT}-22^{\circ} \mathrm{C}$ & $\mathrm{GT}-37^{\circ} \mathrm{C}$ & $\mathrm{SF}-37^{\circ} \mathrm{C}$ \\
\hline Borehole W22 Mnassra & 0 & 0 & 4 & 2 & 0 \\
\hline Borehole W23 Mnassra & 0 & 0 & 1 & 4 & 0 \\
\hline Borehole W24 Bir Rami & 0 & 0 & 13 & 9 & 0 \\
\hline Borehole W25 Mehdia & 0 & 0 & 3 & 0 & 0 \\
\hline Borehole W26 Sidi Tayebi & 0 & 0 & 0 & 0 & 0 \\
\hline Borehole W27 Bouknadel & 0 & 0 & 3 & 6 & 0 \\
\hline Mean & 0 & 0 & 4 & 3 & 0 \\
\hline Morocco Standards & $0 / 100 \mathrm{ml}$ & 0/100ml & $100 / \mathrm{ml}$ & $20 / \mathrm{ml}$ & 0/100ml \\
\hline
\end{tabular}

${ }^{\mathrm{a} B a c t e r i a}$ analysis at RAK laboratory (2012); ${ }^{\mathrm{b}} \mathrm{CF}$ : Faecal coliforms, CT: total coliforms, GT: total germs, SF: faecal streptococci.

Table 11. Comparison of Maâmora’s tablecloth with others quifers and standards.

\begin{tabular}{|c|c|c|c|c|c|c|}
\hline \multirow{2}{*}{ Parameters } & \multicolumn{6}{|c|}{ Aquifers Standards } \\
\hline & Maâmora & Moroccan & WHO 2007 & French 1993 & Egypt 2005 & Tunisia 2003 \\
\hline $\mathrm{T}^{\circ} \mathrm{C}$ & 20.43 & 25 & 25 & 25 & 25 & 25 \\
\hline $\mathrm{pH}$ & 7.3 & 6.5 à 8.5 & 6.5 à 8.5 & 6.5 à 8.5 & 6.5 à 8.5 & 6.5 à 8.5 \\
\hline $\mathrm{EC} \mu \mathrm{S} / \mathrm{cm}$ & 1137.05 & 2700 & 2500 & 2500 & 2700 & 2500 \\
\hline Turbidity NTU & 3.75 & 5 & 5 & 5 & 5 & 5 \\
\hline TH mg/l & 36.27 meq/L & 50 meq/L & 500 & 500 & 200 & 500 \\
\hline $\mathrm{HCO}_{3}^{-} \mathrm{mg} / \mathrm{l}$ & 258.87 & 50 meq & 400 & 400 & 300 & 400 \\
\hline $\mathrm{NO}_{3}^{-} \mathrm{mg} / \mathrm{l}$ & 30.67 & 50 & 50 & 50 & 50 & 50 \\
\hline $\mathrm{NO}_{2}^{-} \mathrm{mg} / \mathrm{l}$ & 0,032 & 0.5 & 0.5 & 0.1 & 0.2 & 0.1 \\
\hline $\mathrm{SO}_{4}^{2-} \quad \mathrm{mg} / \mathrm{l}$ & 74.16 & 400 & 250 & 250 & 250 & 250 \\
\hline $\mathrm{Cl}^{-} \mathrm{mg} / \mathrm{l}$ & 256.16 & 750 & 250 & 250 & 250 & 250 \\
\hline $\mathrm{NH}_{4}^{+} \quad \mathrm{mg} / \mathrm{l}$ & 1.09 & 0.5 & 0.5 & 0.5 & 0.2 & 0.5 \\
\hline $\mathrm{O}_{2} \mathrm{mg} / \mathrm{l}$ & 5.47 & 5 à 8 & 5 à 8 & 5 à 8 & 5 à 8 & 5 à 8 \\
\hline Oxydisability & 3.2 & 5 meq & 5 & 5 & 5 & 5 \\
\hline Boron mg/l & 0.026 & 0.3 & 0.3 & 0.01 & 0.7 & 0.01 \\
\hline $\mathrm{F}^{-} \mathrm{mg} / \mathrm{l}$ & 0.21 & 1.5 & 1.5 & 1.5 & 1.5 & 1.5 \\
\hline $\mathrm{SiO}_{2} \mathrm{mg} / \mathrm{l}$ & 4.54 & 100 & 100 & 100 & 100 & 100 \\
\hline Dry Residue mg/l & 0.1246 & 0.5 & 0.5 & 1500 & - & 1500 \\
\hline Bacteria & 4 & $0 / 100$ & 0 & 0 & 0 & 0 \\
\hline
\end{tabular}

However, the water is marked Maâmora nitric because the concentration of about 91.09 mg/L (W22; Mnassra), 163.68 mg/L (W21; Bouknadel) and 210.8 mg/L (W18; Bir Rami) far above the standard (50 mg/L) set by the World Health Organization [3]. The nitrate constitutes a threat to the man in the process of consumption [7] [8].

Therefore, the metal analysis shows that values are still well below the authorized maximum for boron, zinc, fluoride, cadmium, cooper, iron. But the concentration of lead ranges from 45.4 to $185.6 \mu \mathrm{g} / \mathrm{L}$ and are very high to the norm of $10 \mu \mathrm{g} / \mathrm{L}$. The same for nickel $58.98 \mu \mathrm{g} / \mathrm{L}$ is much greater than the standard and poses a serious 
problem for the consumption of water from the Mâamora's groundwater. We also note that the concentration of iron in Bouknal's boreholes is very high $(187.3 \mathrm{mg} / \mathrm{L})$ and the concentration of zinc in Bir Rami's boreholes is very high $(2204 \mathrm{mg} / \mathrm{L})$ and may pose a long-term problem due to bioaccumulation through the food chain and direct way.

The operation is based on results of the comparison between the Moroccan standards and data analysis carried out on samples of raw water.

The results of the physicochemical analyses presented in this work show that the $\mathrm{pH}$, temperature, organic matter and sulfates can be considered eligible and have no impact on water quality. Thus, the average $\mathrm{pH}$ values (7.3), temperature $\left(20.43^{\circ} \mathrm{C}\right)$ and sulfate $(74.16 \mathrm{mg} / \mathrm{L})$ are consistent with the standards of supply waters [1]. These results are in agreement with those obtained on the waters of groundwater Mnassra (Morocco) [9] and Gharb (Belksiri) [10].

Maâmora's waters are highly sought, on the one hand, to supply drinking water Gharb basin, Rabat the capital and economic center of Morocco (Casablanca), on the other hand, to meet the needs of the industrial and agricultural sector. Hence the need to use the tools is necessary to preserve, characterize and quantify the quality of these resources [4]. The analysis and interpretation show piezometric groundwater flow to the Gharb plain and the Atlantic Ocean. The lithology of permeable land consists mainly of sand, sandstone, conglomerate, limestone and clay. Together they form a Plio-Quaternary aquifer based on a Mio-Pliocene bedrock (blue marl) [11].

The variation of the concentration of nitrates found among different wells may be related to the heterogeneity among different physical environments. For Reference [12], the large spatial variability of nitrate at Maâmora study area is due to the surface texture and lithology. However, the proportion of wells nitrate is low, the high proportion of nitrates can be caused by the use of chemical fertilizers in agriculture. The heavy rainfall and lack of vegetation cover contribute to the rapid leaching of nitrates to Maâmora's groundwater [12]-[15]. Similarly, [16] found that the winter period was the critical phase of leaching of excess nitrogen in groundwater in the Rhine valley in France because of the lack of vegetation and the impact of heavy rainfall. Also the high level of nitrates is observed in Europe, Senegal and attributed to intensification of agriculture and its impact [17]-[19].

Moreover, in the Maâmora's water there are no indicators of fecal contamination in protected boreholes, in agreement with those found [20]-[23] for the sheet of Marrakech an d Sidi Kacem (Morocco) and Nouakchett (Mauritania). These results are similar to those of [24] [25] good limit for drinking water.

Physicochemical and bacteriological values of our studies are lower than the Moroccan standards, WHO (2007), France (1993), Egypt (2005) and Tunisia (1993) (Table 11). Except that the concentration of nitrate exceeds the standards listed above.

\section{Conclusions}

The results of physicochemical analyses of drillings studied are consistent with Moroccan standards for drinking water. The results of physicochemical analyses on key parameters measured indicators show a normal temperature in boreholes. The $\mathrm{pH}$ values measured are excellent. Comparing the values of the electrical conductivity with the water grid can be inferred that the water of Maâmora are good, and analysis of physicochemical parameters (nitrite, nitrate, ammonium, chloride, fluoride, boron, silicate, sulfate ions,..., etc.) remains stable and consistent with Moroccan standards. However, the exponential growth in demand for water and the significant deterioration experienced by the water resources through various forms of pollution leads to the plan and management of water resources, especially drinking water.

Therefore, the preventive aspect should focus more on regular monitoring of water quality or may be on the production of drinking water as well as the control of sources of pollution threatening the water.

\section{Acknowledgements}

The authors express their acknowledgments to the heads of laboratories CNRST-UATRS, ONEP, ORMVAG and RAK in Rabat and the Gharb-Kenitra Region.

\section{References}

[1] REEM (2001) Water and Environment Report on the State of the Environment of Morocco. 2nd Edition, Ministry of Spatial Planning, Department of Environment, National Observatory of Morocco Environment (ONEM).

[2] Laferriere, M.J., Minville, J., Lavoie, J. and Payment, P. (1996) The Hog Industry and Risks to Human Health. Bulle- 
tion of Information Health Environment, 7, 1-4.

[3] World Health Organization (WHO) (1986) Ottawa Charter for Health Promotion. WHO Regional Office for Europe, Copenhagen.

[4] Zouhri, L. and Carlier, E. (2002) Hydrochemical Features of a Coastal Aquifer, Morocco. Journal of Environmental Hydrology, 10, 2.

[5] Rodier, J. (1996) The Analysis of Water: Natural Water, Wastewater, Sea Water: Physical, Chemistry, Bacteriology and Biology. 8th Edition, Dunod Ltd, Paris.

[6] Duncun, D.B. (1955) Multiple Rang and Multiple F Tests. Biometrics, 11, 1-42. http://dx.doi.org/10.2307/3001478

[7] National Drinking Water Office Morocco (1999) Drinking Water Supply, Pollution Threats. ONEP.

[8] El Bouqdaoui, K., Aachib, M., Blaghen, M. and Kholtei, S. (2009) Modelling of Nitrate Pollution of Groundwater Berrechid, Morocco. Africa Science, 5, 99-113.

[9] Bricha, S., Ounine, K., Oulkheir, S., Elhaloui, N. and Attarassi, B. (2007) Study of the Physicochemical and Bacteriological Quality of the Water Table Mnassra (Morocco). Africa Science, 3, 391-404.

[10] Akhiar, S. (2009) Groundwater Characterization City Mechraa BelKsiri. Master, Ibn Tofail University, Kenitra.

[11] Zouhri, L. (2000) Structure and Hydrodynamic Modeling of the Aquifer of the Maamora (Morocco). Ph.D. Thesis, Lille University, Lille.

[12] Saadi, Z., Maaslouhi, A., Zeraouli, M. and Gaudet, J.P. (1999) Analysis and Modeling of Seasonal Variations in Nitrate Concentrations in Groundwater in the Aquifer Mnassra, Morocco. Comptes Rendus de l'Academie des Sciences Series II. A Earth and Planetary Science, 329, 579-586.

[13] Zeraouli, M. (1993) Nitrate Pollution. First Results of the Current Situation in the Tablecloth of Mnasra (December 1992-January 1993). Regional Office for Agricultural Development Gharb, Department of Agricultural Development, Department of Agricultural Development Studies, Office of Agro Pedology Internal Publication ORMVAG, September 1993.

[14] Benyakhlef, M., Naji, S., Belghyti, D., Elguamri, Y. and Hassouni, T. (2011) Quality of Drinking Water in the Gharb Region (Kenitra, Morocco). Online Open Access Journal Sciencelib, Volume 3, No. 111005, ISSN 2111-4706.

[15] El Hammoumi, T. and Belghyti, D. (2012) Physicochemical Characterization of Drinking Water Product by Mkansa Treatment Plant Fez Morocco. Online Open Access Journal Sciencelib, Volume 3, No. 111005, ISSN 2111-4706

[16] Zilliox, L., Schenc, C., Kobus, H. and Huwe, B. (1990) Nitrate Pollution: What Remedies? Research Suppl. the Challenges of Agriculture in Europe, 227, 18-21.

[17] Tandia, A.A., Gaye, C.B. and Faye, A. (1997) Origin of High Nitrate Levels in the Groundwater of Quaternary Sands Region of Dakar, Senegal. Sécheresse, 8, 291-294.

[18] Krira, A., Chakour, B. and Fouta, H. (2001) Intensification of Agriculture and Its Impact on the Environment. If Nitrates in Groundwater Mnassra Slick Ghab. Proceedings on Development Agric. Rech. Agron.

[19] Landreau (1990) Water Pollution by Nitrates. Water and Development, 2, 48-49.

[20] Boutin, C. and Dias, N. (1987) Impact of Land Application of Sewage from the City of Marrakech on the Water Table. Bull. Fac. Sci. Marrakech (Sect. Sci. Life), 3, 5-25.

[21] Sadek, S., Benel Harkati, F., Elkharrim, K., Jeddi, F., Rhiate Moufouad, I., Elmarkhi, M., Khadmaoui, A., Mouden, S., Dakir, Z. and Belghyti, D. (2013) The Bacterial Load of Hospital Discharges (Sidi Kacem, Morocco). Advances in Microbiology, 3, 511-514. http://www.scirp.org/journal/aim http://dx.doi.org/10.4236/aim.2013.37068

[22] N'diaye, A.D., Mosa, O.K. and Baidy, L. (2011) Contribution of the CPA and the Physical Parameters in the Evaluation of Fecal Coliforms in the Effluent of the Perimeter Maraicher Sebkha, Nouakchott. ScienceLib Editions Mersenne, Volume 3, No. 111113, ISSN 2111-4706.

[23] Coyne, M.S. and Howell, J.M. (1994) Agricultural Impacts on Fecal Contamination of Shallow Groundwaters in the Bluegrass Region of Kentucky. Soil Science News and Views, 15, 1-3.

[24] ONEP (1995) Water Analysis Methodology in the Laboratory Procedure. Report ONEP, Rabat.

[25] ONEP (1998) Pollution Control of Water Intended for Drinking Water Supply. Ed. ONEP, Rabat. 